\title{
Production of recombinant antibody fragments in Bacillus
} megaterium

\author{
Eva Jordan ${ }^{1}$, Michael Hust*1, Andreas Roth², Rebekka Biedendieck², \\ Thomas Schirrmann ${ }^{1}$, Dieter Jahn² and Stefan Dübel ${ }^{1}$
}

\begin{abstract}
Address: ${ }^{1}$ Technische Universität Braunschweig, Institut für Biochemie und Biotechnologie, Abteilung Biotechnologie, Spielmannstr. 7, 38106 Braunschweig, Germany and 2Technische Universität Braunschweig, Institut für Mikrobiologie, Spielmannstr. 7, 38106 Braunschweig, Germany

Email: Eva Jordan - e.jordan@tu-bs.de; Michael Hust* - m.hust@tu-bs.de; Andreas Roth - andreas.roth@tu-bs.de; Rebekka Biedendieck - r.biedendieck@tu-bs.de; Thomas Schirrmann - th.schirrmann@tu-bs.de; Dieter Jahn - d.jahn@tu-bs.de; Stefan Dübel - s.duebel@tu-bs.de

* Corresponding author
\end{abstract}

Published: 15 January 2007

Microbial Cell Factories 2007, 6:2 doi:10.1 186/1475-2859-6-2
Received: 8 December 2006

Accepted: 15 January 2007

This article is available from: http://www.microbialcellfactories.com/content/6/1/2

(C) 2007 Jordan et al; licensee BioMed Central Ltd.

This is an Open Access article distributed under the terms of the Creative Commons Attribution License (http://creativecommons.org/licenses/by/2.0), which permits unrestricted use, distribution, and reproduction in any medium, provided the original work is properly cited.

\begin{abstract}
Background: Recombinant antibodies are essential reagents for research, diagnostics and therapy. The well established production host Escherichia coli relies on the secretion into the periplasmic space for antibody synthesis. Due to the outer membrane of Gram-negative bacteria, only a fraction of this material reaches the medium. Recently, the Gram-positive bacterium Bacillus megaterium was shown to efficiently secrete recombinant proteins into the growth medium. Here we evaluated $B$. megaterium for the recombinant production of antibody fragments.
\end{abstract}

Results: The lysozyme specific single chain $\mathrm{Fv}(\mathrm{scFv}$ ) fragment $\mathrm{DI} .3$ was succesfully produced using B. megaterium. The impact of culture medium composition, gene expression time and culture temperatures on the production of functional scFv protein was systematically analyzed. A production and secretion at $41^{\circ} \mathrm{C}$ for $24 \mathrm{~h}$ using TB medium was optimal for this individual scFv. Interestingly, these parameters were very different to the optimal conditions for the expression of other proteins in B. megaterium. Per L culture supernatant, more than $400 \mu \mathrm{g}$ of recombinant $\mathrm{His}_{6}$ tagged antibody fragment were purified by one step affinity chromatography. The material produced by $B$. megaterium showed an increased specific activity compared to material produced in $E$. coli.

Conclusion: High yields of functional scFv antibody fragments can be produced and secreted into the culture medium by $B$. megaterium, making this production system a reasonable alternative to $E$. coli.

\section{Background}

Recombinant antibodies and antibody fragments are important tools for research, diagnostics [1] and therapy [2]. Further, the generation of monoclonal antibodies for proteome research, ideally against each human protein, is a massive challenge [3]. Here, phage display has evolved into a valuable method for the selection of antibody fragments for this purpose [4]. Recombinant antibody fragments can be selected from huge antibody gene libraries against any target by an in vitro panning procedure $[5,6]$. Furthermore, the panning procedure can be integrated into high throughput technologies [7]. For the production 
of large numbers of selected antibodies the established systems like mammalian cell culture [8], Pichia pastoris [9] or plants [10] are expensive, complicated and time consuming. The recombinant production of antibody fragments requires the folding and association of at least two different domains ( $\mathrm{VH}$ and $\mathrm{VL}$ ) and includes the formation of disulphide bonds. This results in lower yields compared to single domain enzymes. Overall, the production rate is strongly dependent on the individual sequence of the antibody. However, using appropriate bacterial signal peptides, antigen binding Fv fragments consisting of the $\mathrm{VH}$ and VL domain of an antibody have been produced in E. coli [11]. Improved yields of functional material were achieved by the linking of VH and VL by a $15-25$ amino acid linker, resulting in the production of a single polypeptide, the $\mathrm{scFv}$ (single chain fragment variable) $[12,13]$. However, Gram-negative bacteria like E. coli secrete proteins mostly into the periplasm [14]. Only in rare cases can the scFv be isolated in higher amounts from the supernatant [15]. The use of a Gram-positive bacterium could facilitate the scFv production due to the lack of an outer membrane allowing direct secretion of proteins into the growth medium. The Gram-positive bacteria Bacillus brevis [16,17] and Bacillus subtilis $[18,19]$ have already been succesfully used for the production of antibody fragments. In contrast to B. subtilis, B. megaterium does not produce alkaline proteases. Another advantage of this bacterium is the high stability of plasmids during growth [20], which allows a stable gene expression in long term cultivations and bioreactors. $B$. megaterium has been used for the production of several recombinant proteins, e.g. dextransucrase [21], glucanase [22] and Clostridium difficile toxin A [23]. Recently, a set of free replication vectors and genetically optimized $B$. megaterium strains for the intra- and extracellular production of affinity tagged recombinant proteins were developed. They were succesfully employed for the production and purification of dextransucrase [21], levansucrase [24,25], penicillin amidase [26] and a hydrolase [27].

Methods for large scale high cell density bioreactor cultivation were established $[28,29]$. Here, we evaluate B. megaterium for its capability to produce and secrete recombinant antibody fragments.

\section{Results}

\section{Construction of the pEJBmDI.3scFv vector}

The vector $\mathrm{pEJBmD} 1.3 \mathrm{scFv}$ for the production and the export of the lysozyme specific single chain $\mathrm{Fv}(\mathrm{scFv})$ antibody fragment was constructed from the $B$. megaterium expression vector pHIS1525 [25]. To obtain pEJBmopSplipA codon usage optimized DNA encoding the signal peptide $\mathrm{sp}_{\text {lipA }}$ of $B$. megaterium lipase $A$ was integrated and a residual $E$. coli tetracycline gene fragment was removed from the vector. The scFv gene fragment encoding the murine anti-hen egg white lysozyme antibody D1.3 $[30,31]$ was amplified by polymerase chain reaction (PCR) from the vector pHAL1-D1.3scFv, a pHAL1-D1.3 variant [32], and cloned into pEJBmopSplipA, resulting in

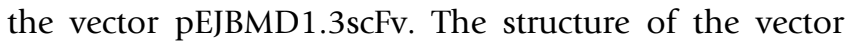
$\mathrm{pEJBmD} 1.3 \mathrm{scFv}$ is given in figure 1. Efficient cloning of gene fragments encoding antibody fragments in E. coli DH10B was sustained by the cotransformation of pMMEc4 encoding the xylose repressor gene $x y l \mathrm{R}$ under control of an arabinose promoter. Continuous $x y l \mathrm{R}$ expression led to the succesful repression of the otherwise leaky B. megaterium xylA promoter in E. coli. After transformation of $B$. megaterium with this vector and the induction of gene expression with xylose, antigen binding by culture supernatant was confirmed by lysozyme ELISA (experimental setup as shown in Fig. 2) (data not shown). However, the initial yields were low and required significant optimization.

\section{Production temperature}

The impact of the temperature on the xylose induced production of $\mathrm{scFv}$ in B. megaterium was evaluated first. Eight different temperatures from $23^{\circ} \mathrm{C}$ to $45^{\circ} \mathrm{C}$ were analyzed using LB medium for cultivation and a gene expresion time of $24 \mathrm{~h}$. The yields of functional scFv were estimated by antigen enzyme-linked immunosorbent assay (ELISA) on lysozyme. The best yield of functional D1.3 fragments was obtained at a cultivation temperature of $41^{\circ} \mathrm{C}$ (Fig. $2)$. Interestingly, in contrast to E. coli secretion systems, yields did not drop significantly at even higher temperatures than $37^{\circ} \mathrm{C}$.

\section{Optimal medium}

D1.3 $\mathrm{scFv}$ production at $41^{\circ} \mathrm{C}$ for $18 \mathrm{~h}$ was induced in minimal media $\mathrm{M} 9$ or A5, LB medium and the rich media $2 \mathrm{xTY}$ and $\mathrm{TB}$, respectively. The secreted $\mathrm{scFv}$ protein was analyzed for antigen binding function by antigen ELISA (Fig. 3A) and for its molecular mass and potential degradation by SDS polyacrylamid gel electrophoresis (SDSPAGE) and immunobloting (Fig. 3B). The minimal media did not allow production of functional scFv. The use of LB medium resulted in a low production of functional scFvs. Significant production of funtional scFvs was observed using the rich medium 2xTY. The highest production was achieved by using TB medium which is the richest of the used media. Here, the immunoblot indicated some degradation products.

\section{Expression time}

The optimal expression time for scFvs in $B$. megaterium was determined at $41{ }^{\circ} \mathrm{C}$ using TB medium for activation. Samples were taken from the supernatant between 0 and $48 \mathrm{~h}$ after induction of the recombinant gene expression with xylose and analyzed by antigen ELISA (Fig. 4A) and immunoblot (Fig. 4B). Functional scFv fragments were 

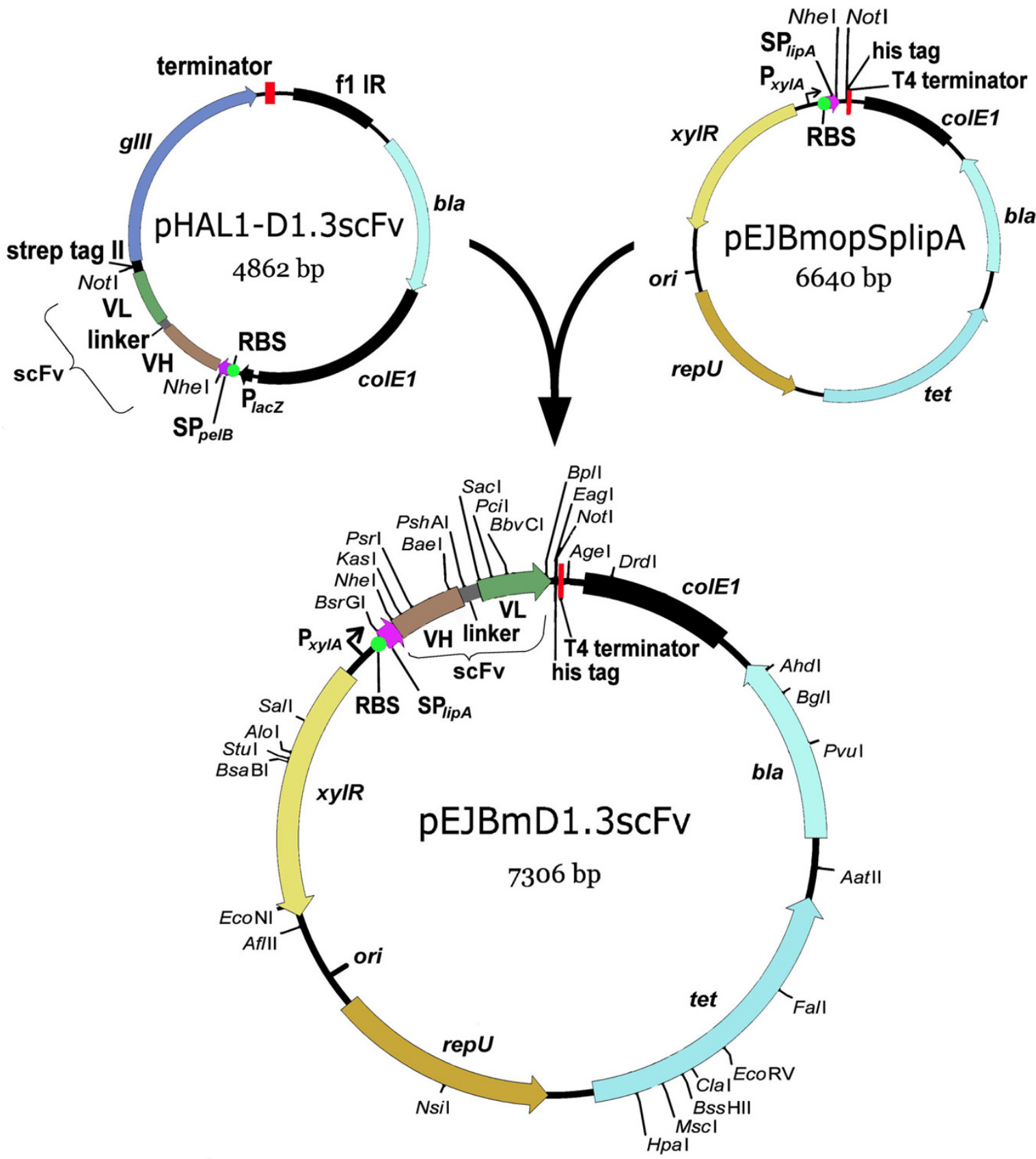

Figure I

Construction of plasmid pEJBmDI.3scFv for the production of scFv antibody fragment DI.3 in B. megaterium. The complete scFv ORF plus the complete promoter region were verified by nucleotide sequencing. Abbreviations: bla: $\beta$-lactamase gene for ampicillin resistence; colEI: $E$. coli origin of plasmid replication; $\mathrm{FI} I \mathrm{R}$ : intergenic region of phage $\mathrm{fI}$; glll: $\mathrm{fd}$ phage gene III; His-tag: synthetic tag binding to $6 x$ histidine; ori: $B$. megaterium origin of plasmid replication; $P_{\text {lacz }}$ : promoter of the bacterial lac operon; $\mathrm{P}_{x y / A}$ : xylose inducible promoter; RBS: ribosome binding site; repU: a gene essential for plasmid replication in $B$. megaterium; scFv: single chain fragment variable; $\mathrm{SP}_{\text {lipA }}$ : signal peptide sequence of $B$. megaterium extracellular esterase LipA; $\mathrm{SP}_{\text {pelB: }}$ signal peptide sequence of bacterial pectate lyase; strep-tag II: synthetic tag binding to streptactin; terminator: sequence terminating transcription; tet: tetracyclin resistence gene; $\mathrm{VH}$ : sequence encoding the variable fragment of the heavy chain; $\mathrm{VL}$ : sequence encoding the variable fragment of the light chain chain; $x y I R$ : xylose repressor 


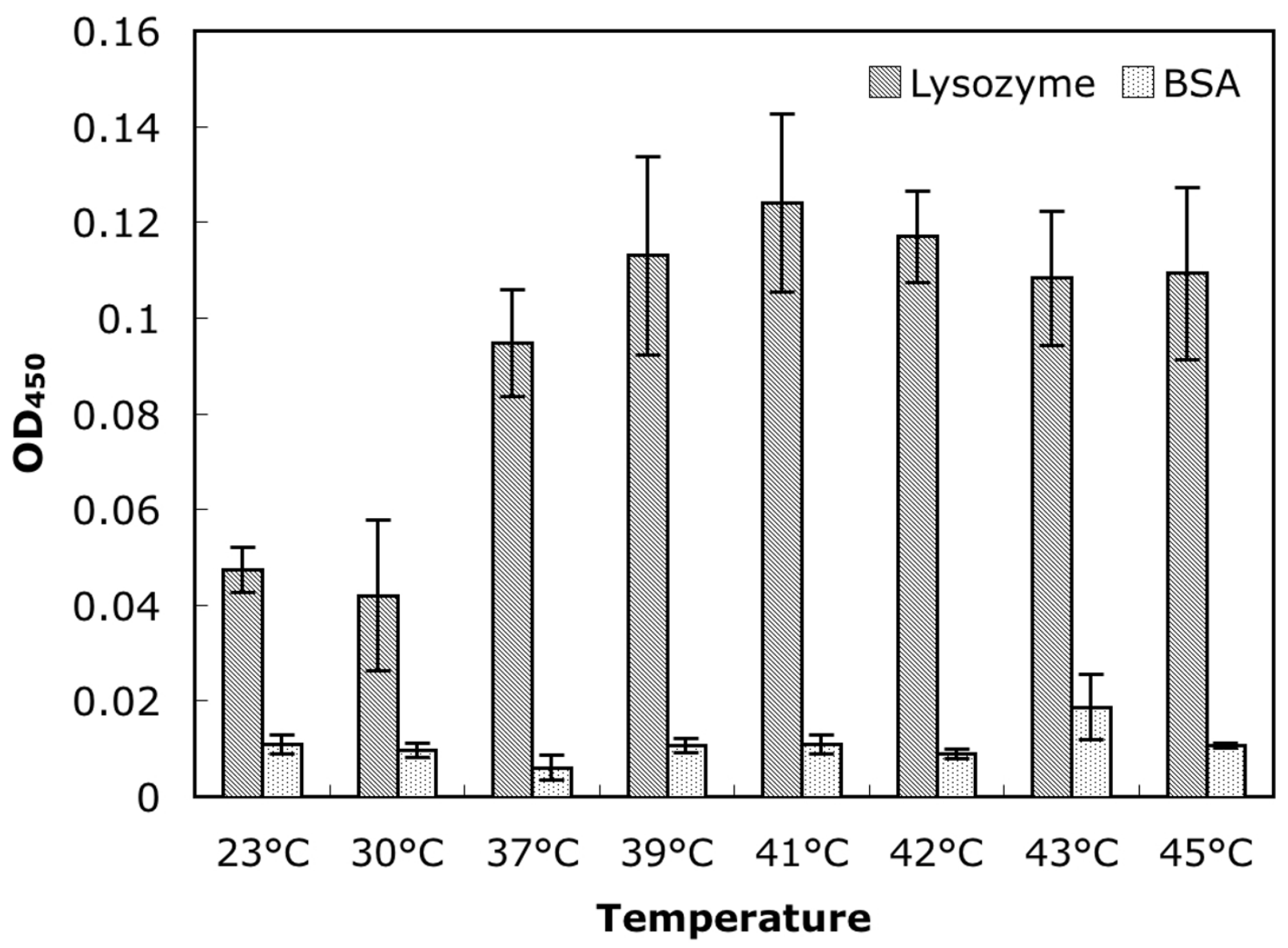

\section{Figure 2}

Impact of the cultivation temperature on the scFv production. Production of functional antibodies was analyzed by antigen binding ELISA of DI.3 scFvs of $50 \mu \mathrm{L}$ culture supernatant after $24 \mathrm{~h}$ production in $100 \mathrm{~mL}$ scale. Mean values and standard deviations of data obtained from three different cultures are given. Antigens: I $\mu \mathrm{g} /$ well lysozyme or I $\mu g /$ well control protein BSA. The DI.3 antibodies were detected using mAb mouse anti-His and goat anti-mouse IgGHRP (Fab specific).

detectable $6 \mathrm{~h}$ after induction. The amount of secreted scFv protein continuously increased until 24 hours after induction. A longer cultivation time resulted in a slight reduction of functional $\mathrm{scFv}$ with the total amount of antibody fragments still increasing. From $12 \mathrm{~h}$ on, degradation products of the antibody fragment were detected.

\section{Comparison of B. megaterium and E. coli}

The anti-lysozyme D1.3 scFv was purified from culture supernatant of $B$. megaterium or E. coli periplasm and supernatant. The material was purified by immobilized metal affinity chromatography (IMAC). A yield of $410 \mu \mathrm{g} /$ $\mathrm{L} \mathrm{scFv}$ after purification was obtained from B. megaterium, whereas $290 \mu \mathrm{g} / \mathrm{L}$ were obtained from E. coli.
Serial dilutions of the purified scFv D1.3 produced by either $E$. coli or B. megaterium were analyzed by antigen ELISA on lysozyme (Fig. 5). The scFvs produced in B. megaterium showed higher specific antigen binding compared to the scFvs produced in E. coli, when same amounts of antibody fragments were applied to ELISA.

Both the higher concentration and the better specific activity indicate an improved enrichment from $B$. megaterium culture supernatant by a single IMAC purification step, when compared to E. coli material.

\section{Discussion}

For many applications of antibodies, full length IgG material is not mandatory. For example, for research and diag- 
A

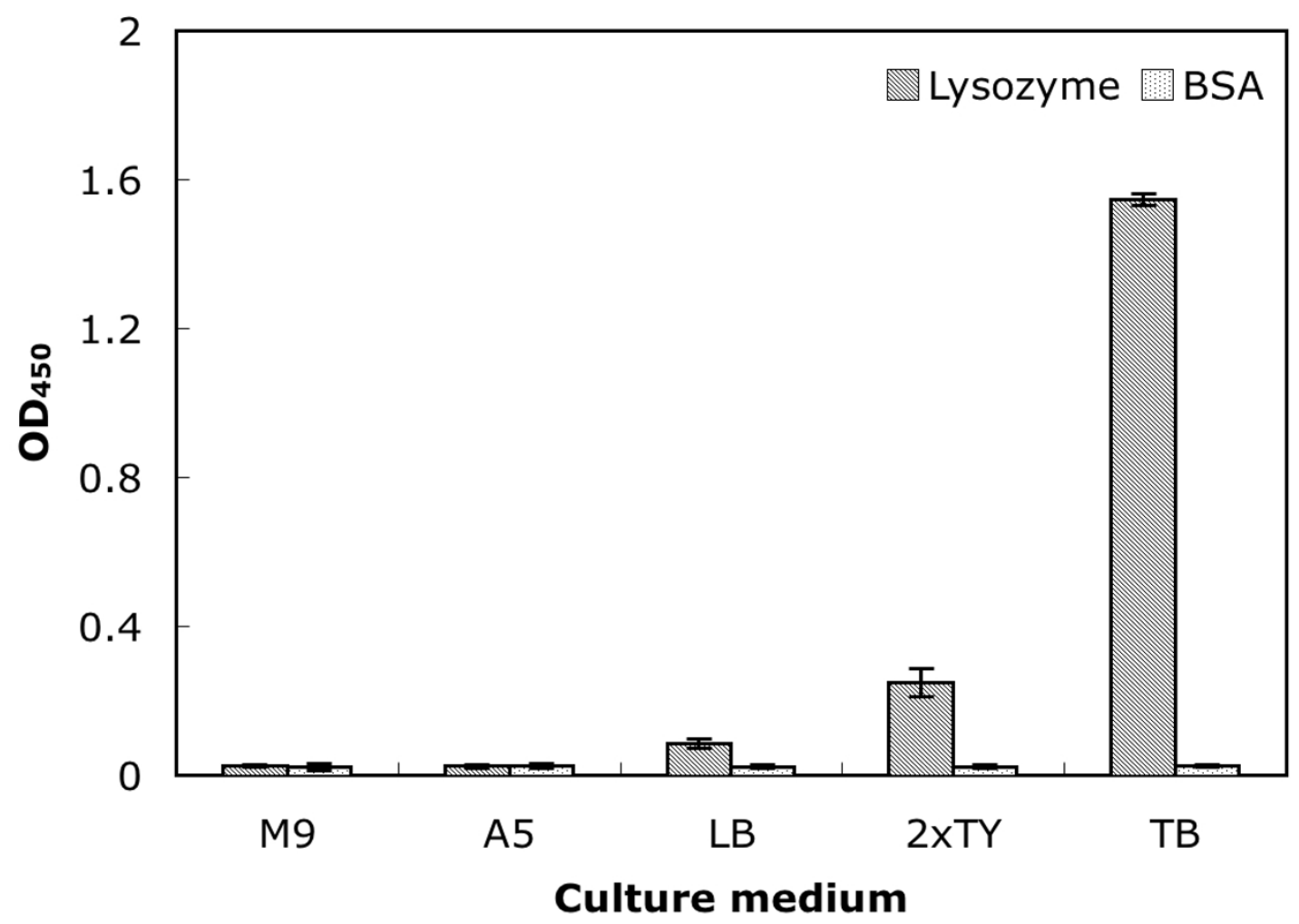

B

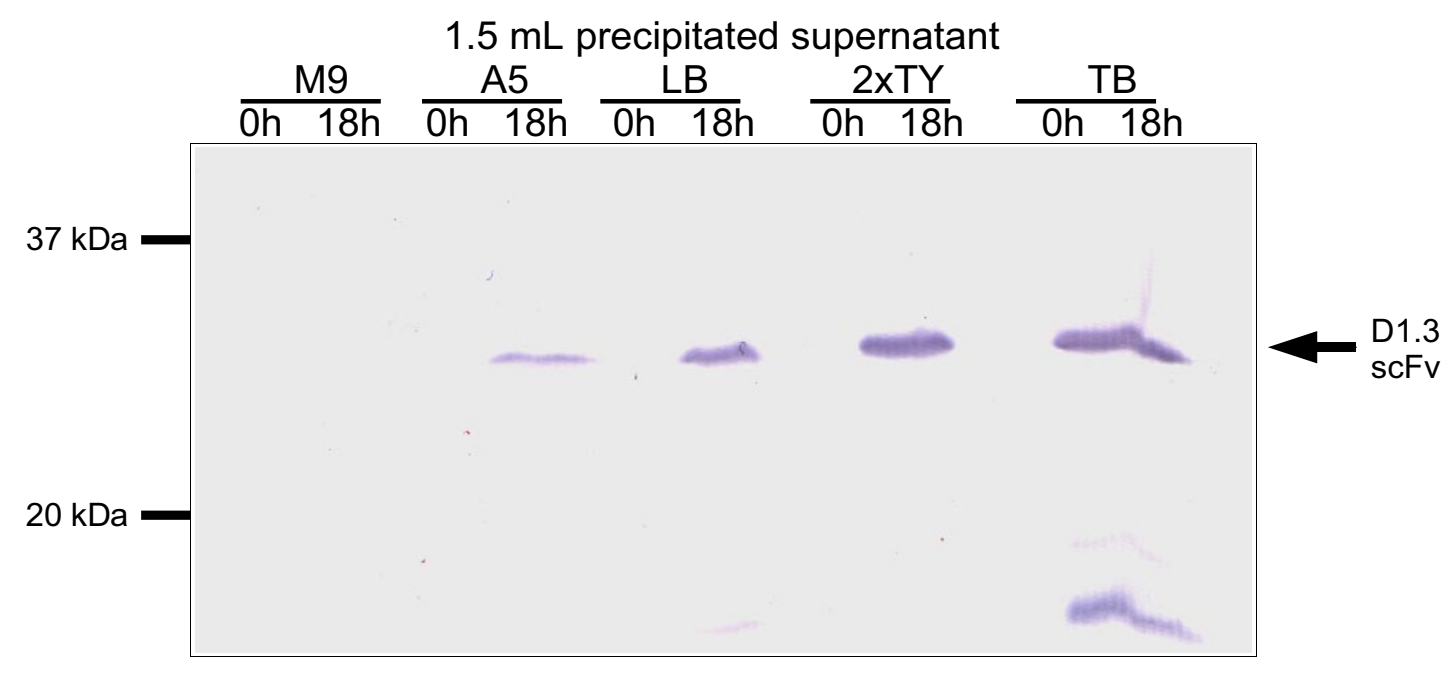

\section{Figure 3}

Impact of different culture media on the production of functional scFvs. A Antigen binding ELISA with $50 \mu \mathrm{L}$ culture supernatant from $18 \mathrm{~h}$ production in $100 \mathrm{~mL}$ scale, performed as described in figure 2. Mean values and standard deviations of data obtained from three different cultures are given. B Immunoblot of culture supernatant. Ammonium sulfate precipated scFvs from I.5 mL supernatant were separated by reducing SDS-PAGE (I $\%$ ) and detected using mAb mouse anti-His and goat antimouse IgG AP (Fab specific). 
A

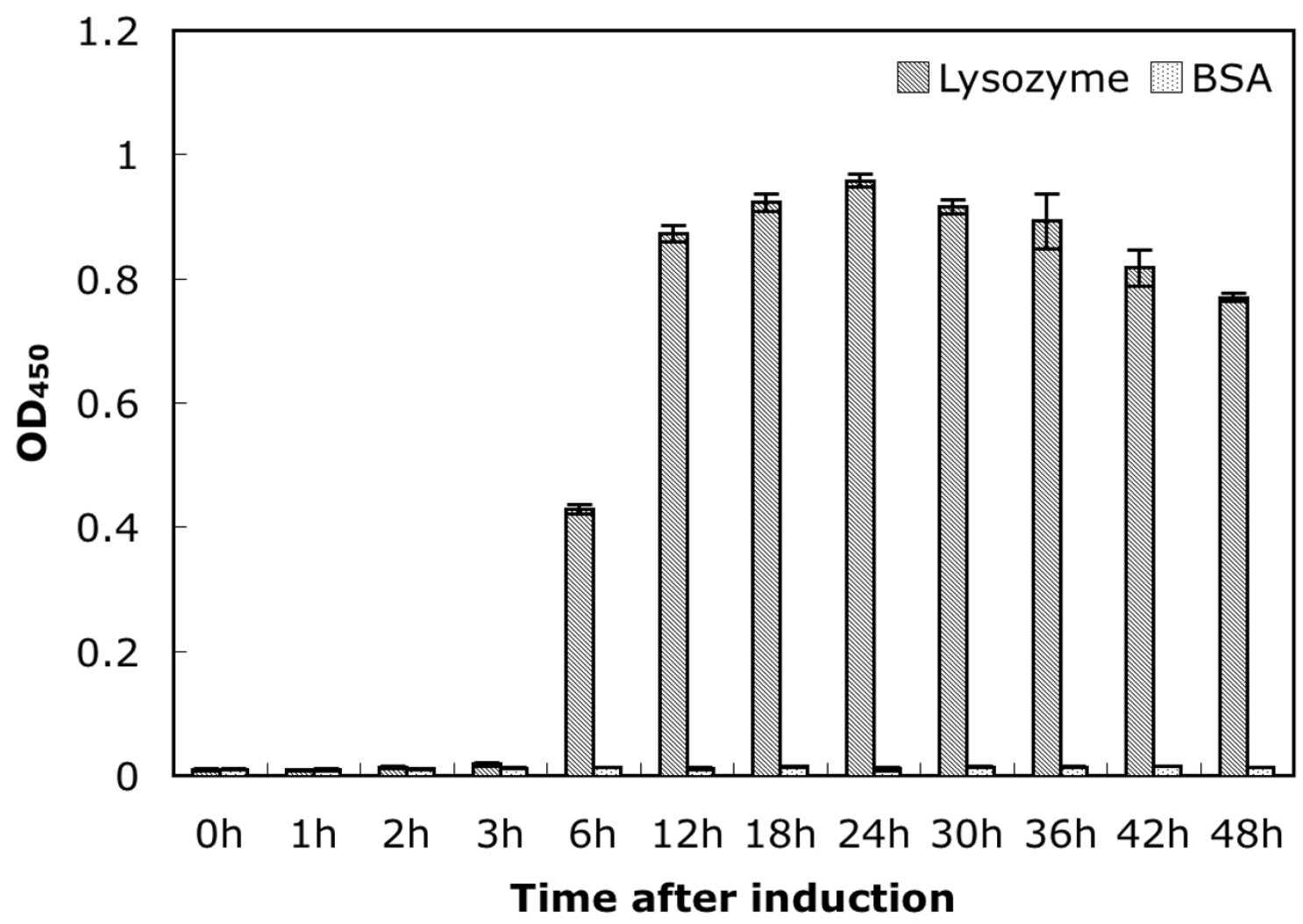

B

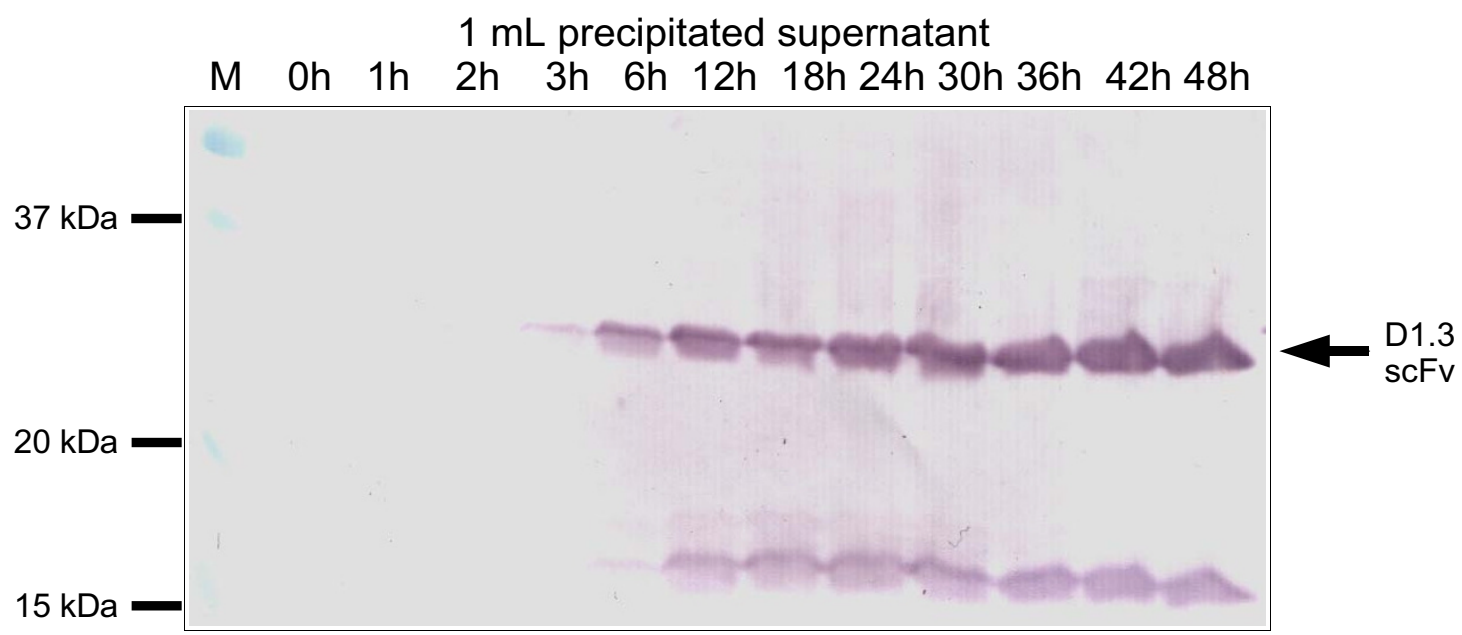

\section{Figure 4}

Impact of the production time on the yield of functional scFvs (TB medium, $41^{\circ} \mathrm{C}$ ). A Antigen binding ELISA with $50 \mu \mathrm{L}$ culture supernatant from different time points, performed as described in figure 2 and 3. Mean values and standard deviations of data obtained from three different cultures are given. B Immunoblot of produced scFvs. Ammonium sulphate precipated scFvs from I $\mathrm{mL}$ supernatant were separated by reducing SDS-PAGE (I2\%) and detected as described in figure 3. 


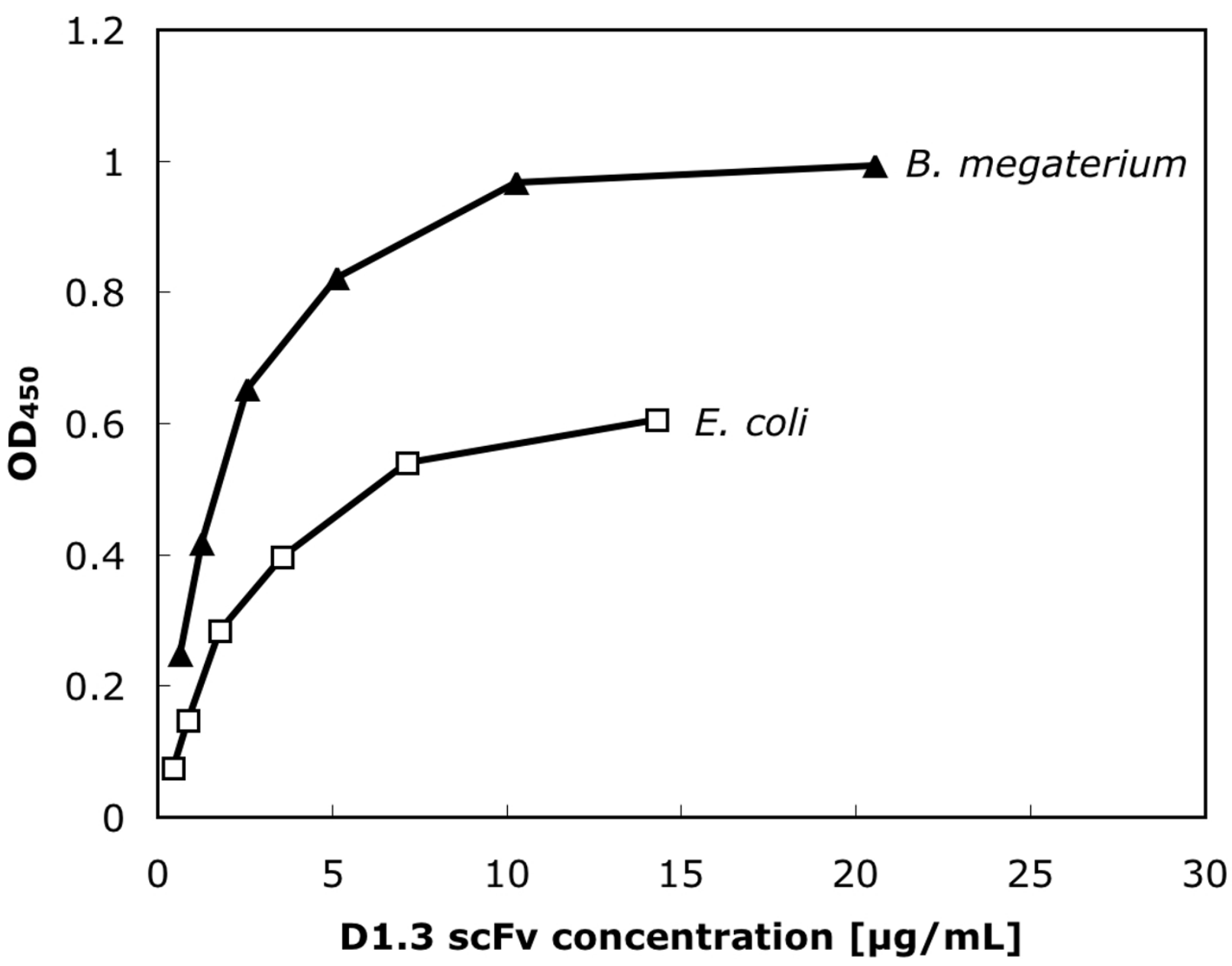

Figure 5

Antigen ELISA of purified DI.3 scFv from E. coli or Bacillus megaterium. Antigen: I $\mu$ g/well lysozyme. The detection was performed as described in figure $2-4$.

nostics, correctly glycosylated IgG produced in mammalian cell lines are not necessary. Antigen binding antibody fragments, like Fab or $\mathrm{scFv}$, are sufficient for many immunological standard assays e.g. immunoblot, ELISA, immunohistochemistry or immunoprecipitation. In contrast to full IgG molecules, these antigen binding fragments can conveniently be produced in E. coli. Although this production system is widely used, corresponding yields are somehow limited and in particular hampered by the inefficient secretion, leaving more than $90 \%$ of the produced scFv e inside of the cell. Moreover, the majority of protein is found denatured in form of insoluble inclusion bodies [33]. These observations stimultated the search for alternative production systems.
Novel production systems could enhance the yield of functional antibody fragments or allow cheaper and easier production and purification. Various microorganism beside E. coli, like B. subtilis [18,19], B. brevis $[16,17]$, Proteus mirabilis [34] or Lactobacillus zeae [35] have been used for the production of recombinant antibody fragments. Among these, Gram-positive bacteria in particular offer the opportunity to avoid the periplasm preparation step by secreting directly into the medium. In this study, the parameters for the $\mathrm{scFv}$ production in $B$. megaterium were established using the anti-lysozyme scFv D1.3 [30,31], an antibody fragment that has already been widely used to evaluate selection a production methods. Remarkably, the optimal yields of functional scFv fragments were obtained 
at $41^{\circ} \mathrm{C}, 24 \mathrm{~h}$ production time and in TB medium. These conditions differ significantly from those established for the production of this protein class in E. coli, Bacillus subtilis or Bacillus brevis. When using E. coli, a broad temperature range using $22^{\circ} \mathrm{C}, 25^{\circ} \mathrm{C}, 30^{\circ} \mathrm{C}$ or $37^{\circ} \mathrm{C}$ was successfully used for the expression of different antibody fragments with a slight advantage of lower temperatures [31,32,36-40]. For B. subtilis $37^{\circ} \mathrm{C}, 6-8 \mathrm{~h}$ expression time and rich medium was used for the expression of scFvs [19], wheras for Bacillus brevis $30^{\circ} \mathrm{C}, 3$ days and THB medium was preferable [17]. For the production of other recombinant proteins in $B$. megaterium, like dextransucrase, $37^{\circ} \mathrm{C}$ was found to be optimal [21]. As it is known that folding is usually the limiting step in antibody production in various organisms $[37,41,42]$, a possible heat shock effect, leading to improved chaperone expression, may explain these differences.

The production of the D1.3 scFv in B. megaterium led to a higher yield of functional antibody fragments compared to our standard E. coli production system, whereas a fraction of degraded scFvs were detected in the B. megaterium production. The production of this particular $\mathrm{scFv}$ can yield up to of $0.8-1 \mathrm{mg} / \mathrm{L}$ using a different $E$. coli expression system after extensive optimization [43]. The B. megaterium production strains have not been optimized compared to the long lasting optimization of E. coli and other Bacillus strains. When using E. coli, a yield of $1-2 \mathrm{~g} /$ $\mathrm{L}$ were obtained when producing a human breast tumor marker protein p185HER2 specific Fab fragment [44]. When using Bacillus strains, e.g. using B. subtilis $10-15$ $\mathrm{mg} / \mathrm{L}$ of a fibrin specific scFv were produced [19] or when using $B$. brevis Fab fragments were produced at a level of $100 \mathrm{mg} / \mathrm{L}$ [16]. Furthermore, the yield is strongly depend on the individual sequence of the produced antibody fragment.

This study showed, that after a single purification step using a recombinant $\mathrm{His}_{6}$-tag, both the concentration of the obtained material and its functional activity are superior to E. coli scFv prepared in parallel.

\section{Conclusion}

$B$. megaterium allows the production of functional $\mathrm{scFv}$ fragments by secretion into the culture medium. The specific activity of material obtained from $B$. megaterium was higher than that obtained from E. coli. Therefore, B. megaterium can be added to the list of microbial production hosts able to handle the demanding folding and secretion of antibody fragments. The $B$. megaterium production system offers a serious alternative to $E$. coli for the production of recombinant antibody fragments, in particular for research and diagnostic purposes.

\section{Methods \\ Vector construction}

Standard cloning procedures were performed according to Sambrook and Russell [45]. The pEJBmD1.3scFv vector was derived from the $B$. megaterium expression vector pHIS1525 [25]. The vector pHIS1525 was modified for the cloning and expression of antibody fragments. For this purpose, the terminator T4 [46] and a sequence encoding the 6xHis-tag were introduced using the two hybridised oligonucleotide primer EJoligoHisTermf and EJoligoHisTermr with the restriction sites SphI and AgeI. A residual part of the E. coli tetracycline resistence gene was deleted by digestion with AflII and religation. Furthermore, the signal peptide $\mathrm{sp}_{\text {lipA }}$ [25] was optimized regarding the codon usage and a NheI restriction site was introduced for further cloning steps using the overlapping oligonucleotide primer EJopSplipAf and EJopSplipAr. The signal peptide gene fragment was cloned into the BglII/BsrGI restriction site, resulting in the vector pEJBmopSplipA. These cloning steps were performed in E. coli DH5 $\alpha$ (Invitrogen, Karlsruhe, Germany). The DNA encoding the D1.3 scFv was amplified from the plasmid pHAL1D1.3scFv, an scFv variant of pHAL1-D1.3 [32], using the oligonucleotide primer EJD1.3NheIf and EJD1.3r and cloned into the NheI/NotI site to yield pEJBmD1.3scFv. This cloning step was performed in E. coli DH10B containing the plasmid pMMEc4, encoding the xylose repressor protein to ensure the repression of the Xylose promoter during the cloning step in E. coli. The plasmid pMMEc4 was derived from pBAD33 (ATCC 87402) by cloning the amplified xylose repressor gene using the oligonucleotide primer XylRfor and XylRrev from B. megaterium DSM319 into the SacI/SphI site. Transformation of E. coli DH10B [pMMEc4] with pEJBmD1.3scFv was performed as outlined before [45]. All affected regions of the constructs were confirmed by DNA sequencing using an ABI Prism 310 sequencer. All oligonucleotide primer sequences are given in Table 1.

\section{Transformation of B. megaterium}

Transformations of non-sporulating B. megaterium strain MS941 [47] were performed as described by Barg et al. [48].

\section{Production and export of scFvs using B. megaterium}

The D1.3 scFv was produced in shaking flasks. $100 \mathrm{~mL}$ medium $+10 \mu \mathrm{g} / \mathrm{mL}$ tetracyline were inoculated with 1 $\mathrm{mL}$ overnight culture at $37^{\circ} \mathrm{C}$ and $250 \mathrm{rpm}$. The media used were A5 pH 6.8 (30 g/L glucose, $2 \mathrm{~g} / \mathrm{L}\left(\mathrm{NH}_{4}\right)_{2} \mathrm{SO}_{4}$, $0.3 \mathrm{~g} / \mathrm{L} \mathrm{MgSO}_{4}, 0.5 \mathrm{~g} / \mathrm{L}$ yeast extract, $3.5 \mathrm{~g} / \mathrm{L} \mathrm{KH}_{2} \mathrm{PO}_{4}, 7.3$ $\mathrm{g} / \mathrm{L} \mathrm{NaHPO}{ }_{4} \times 2 \mathrm{H}_{2} \mathrm{O}, 40 \mathrm{mg} / \mathrm{L} \mathrm{MnCl} \times 2 \mathrm{H}_{2} \mathrm{O}, 53 \mathrm{mg} / \mathrm{L}$ $\mathrm{CaCl}_{2} \times 2 \mathrm{H}_{2} \mathrm{O}, 2.5 \mathrm{mg} / \mathrm{L} \mathrm{FeSO}_{4} \times 7 \mathrm{H}_{2} \mathrm{O}, 2.5 \mathrm{mg} / \mathrm{L}$ $\left.\left(\mathrm{NH}_{4}\right)_{6} \mathrm{Mo}_{7} \mathrm{O}_{24} \times \mathrm{H}_{2} \mathrm{O}, 2.5 \mathrm{mg} / \mathrm{L} \mathrm{CoCl}_{2} \times 6 \mathrm{H}_{2} \mathrm{O}\right), \mathrm{M} 9, \mathrm{LB}$, 2XTY and TB [45]. The induction was started by adding 0.5 $\%$ xylose at O.D. $600 \mathrm{~nm}=0.3-0.4$. The culture was shaken 
Table I:

\begin{tabular}{ll}
\hline EJoligoHisTermf & $5^{\prime}$ cg ccg ctc atc acc atc acc atc act aaa aag ccc tca atg aag agg gct ttt ttt aa $3^{\prime}$ \\
EJoligoHisTermr & $5^{\prime}$ ccg gtt aaa aaa agc cct ctt cat tga ggg ctt ttt agt gat ggt gat ggt gat gag cgg ccg cat g 3' \\
EJopSplipAf & $5^{\prime}$ cgc agt gta caa tga aaa aag tat taa tgg ctt tca tta ttt gtt tat cat taa ttt tat cag tat tag c 3' \\
EJopSplipAr & $5^{\prime}$ cgc aga gat ctt caa tgc ggc gct agc acc tga tgg tgg agc agc taa tac tga taa aat taa tga taa 3' \\
EJDI.3Nhelf & $5^{\prime}$ cgc agg cta gcg ccg aag tta aac tgc agg agt cag gac ct 3' \\
EJDI.3r & $5^{\prime}$ cgc agg cgg ccg cct tca gct cga 3' \\
XylRfor & $5^{\prime}$ ata aag agc tca agg aga caa agg aat ggt tat tat tca aat tgc 3' \\
XyIRrev & $5^{\prime}$ agg ctg cat gcc gtt cac tta act aac tta tag g 3'
\end{tabular}

at $250 \mathrm{rpm}$ and temperatures from $23^{\circ} \mathrm{C}$ to $45^{\circ} \mathrm{C}$ for up to $48 \mathrm{~h}$. The supernatant was directly used for ELISA. For SDS-PAGE analysis and protein purification, the proteins of the supernatant were precipitated using $440 \mathrm{~g} / \mathrm{L}$ ammonium sulfate.

\section{Production of scFvs in E. coli}

The D1.3 scFv was produced in shaking flasks according to Dübel et al. [37] using the vector pOPE101 [49] and the E. coli strain XL1-Blue MRF' (Stratagene, Amsterdam, Netherland). Briefly, $300 \mathrm{~mL} 2 \times \mathrm{TY}+100 \mathrm{mM}$ glucose + $100 \mu \mathrm{g} / \mathrm{mL}$ ampicillin were inoculated with an overnight culture yield to O.D. $600 \mathrm{~nm}=0.1$ and cultured at $37^{\circ} \mathrm{C}$ and $250 \mathrm{rpm}$. The scFv production was induced by adjusting to $50 \mu \mathrm{M}$ IPTG at O.D. $600 \mathrm{~nm}=0.5$ and shaking for $3 \mathrm{~h}$ at $30^{\circ} \mathrm{C}$. Bacteria were harvested by $10 \mathrm{~min}$ at $4400 \times \mathrm{g}$ and $4^{\circ} \mathrm{C}$. The supernatant was used for ammonium sulfate precipitation (see below). Bacteria pellets were resuspended in $30 \mathrm{~mL}$ ice cold PE buffer, pH 8 (20\% sucrose, $50 \mathrm{mM}$ Tris, $1 \mathrm{mM}$ EDTA) and incubated for $20 \mathrm{~min}$ on ice, interrupted by short vortexing every $2 \mathrm{~min}$. Subsequently the bacteria were pelleted for $30 \mathrm{~min}$ at 30,000 $\times$ $\mathrm{g}$ and $4^{\circ} \mathrm{C}$. The supernatant (periplasmic fraction) was stored at $-20^{\circ} \mathrm{C}$. The remaining supernatant from the first bacteria centrifugation was precipated using $132 \mathrm{~g} / 300$ $\mathrm{mL}$ ammonium sulfate, stirred $1 \mathrm{~h}$ at $4^{\circ} \mathrm{C}$ and centrifuged for $20 \mathrm{~min}$ at $7700 \times \mathrm{g}$ and $4^{\circ} \mathrm{C}$. The protein pellet was dissolved in $10 \mathrm{~mL}$ PBS. The periplasmic fraction and the precipitated supernatant were combined and dialysed over night against PBS at $4^{\circ} \mathrm{C}$.

\section{Immobilized metal affinity chromatography (IMAC) purification of antibody fragments}

Antibody fragments were purified from E. coli or B. megaterium derived material by affinity chromatography using IMAC. Chromatography using $1 \mathrm{~mL}$ Chelating Sepharose Fast Flow (Amersham Biosciences, Freiburg, Germany) was performed according to the manufacturers' instruction. The protein solution was adjusted to $10 \mathrm{mM}$ imidazol containing buffer $\left(20 \mathrm{mM} \mathrm{Na} \mathrm{HPO}_{4}, 500 \mathrm{mM} \mathrm{NaCl}\right.$, $10 \mathrm{mM}$ imidazol) for loading The column was washed one time with $10 \mathrm{mM}$ imidazol, twice with $50 \mathrm{mM}$ imidazol buffer and once with PBS. Two times $50 \mathrm{mM}$ $\mathrm{NaH}_{2} \mathrm{PO}_{4}, 300 \mathrm{mM} \mathrm{NaCl}$ and $250 \mathrm{mM}$ imidazol and fin- aly with phosphate buffered saline (PBS) [45], pH 7.4, $100 \mathrm{mM}$ EDTA were used for the elution.

\section{Antigen binding ELISA}

Maxisorb MTPs (Nunc, Wiesbaden, Germany) were coated with $1 \mu \mathrm{g}$ hen egg white lysozyme or $1 \mu \mathrm{g}$ BSA in $100 \mu \mathrm{L}$ PBS per well overnight at $4{ }^{\circ} \mathrm{C}$. Coated wells were washed three times with PBST (PBS $+0,1 \%(v / v)$ Tween 20) and blocked with $2 \%(\mathrm{w} / \mathrm{v})$ skim milk powder in PBST for $1.5 \mathrm{~h}$ at RT, followed by three times washing with PBST. Soluble antibody fragments were diluted in $100 \mu \mathrm{L}$ blocking solution and incubated for $1.5 \mathrm{~h}$, followed by three times washing with PBST. Soluble antibody fragments were detected with mAb mouse anti-penta His-tag (1:10000) (Qiagen, Hilden, Germany) and polyclonal goat anti-mouse IgG conjugated with horse radish peroxidase (HRP) (Fab specific) (1:10000) (Sigma, Taufkirchen, Germany) and visualised with $100 \mu \mathrm{L} \mathrm{TMB}$ $(3,3 ', 5,5$ '-tetramethylbenzidine) substrate. The staining reaction was stopped by adding $100 \mu \mathrm{L} 1 \mathrm{~N}$ sulphuric acid. The absorbances at $450 \mathrm{~nm}$ and scattered light at 620 nm were measured using a microtitre plate reader SUNRISE (Tecan, Crailsheim, Germany). The absorbance at $620 \mathrm{~nm}$ was subtracted.

\section{SDS-PAGE and Immunoblot}

Soluble antibody fragments were separated by SDS-PAGE [50] and blotted onto polyvinyl fluoride (PVDF) membrane (millipore, Schwalbach, Germany). The membrane was blocked with $3 \%(\mathrm{w} / \mathrm{v})$ skim milk powder in PBS for $1 \mathrm{~h}$ at RT. For the detection of soluble antibody fragments the mAb mouse anti-penta His-tag (1:2000) (Qiagen, Hilden, Germany) was used as first antibody and goat anti-mouse IgG (Fab specific) conjugated with alkaline phosphatase (AP) (Sigma, Taufkirchen, Germany) (1:5000) was used as second antibody. The visualisation was done by NBT/BCIP.

\section{Authors' contributions}

EJ performed the experiments and helped to draft the manuscript. $\mathrm{MH}$ drafted the manuscript and participated in the design and coordination of the study. AR and RB constructed the helper plasmid pMMEc4. DJ designed and coordinated the construction of the helper plasmid and 
helped to draft the manuscript. TS and SD participated in the design and coordination of the study and helped to draft the manuscript. SD conceived the project and wrote the grants to fund EJ, TS and MH. All authors read and approved the final manuscript.

\section{Acknowledgements}

We would like to thank Bronwyn M. Kenny for corrections on the manuscript. We gratefully acknowledge the financial support by the German Research Foundation (DFG, SFB 578) and the German ministry of education and research (BMBF, SMP "Antibody Factory" in the NGFN2 program).

\section{References}

I. Hust M, Maiss E, Jacobsen HJ, Reinard T: The production of a genus specific recombinant antibody (scFv) using a recombinant Potyvirus protease. J Virol Meth 2002, I06:225-233.

2. Dübel S: Handbook of therapeutic antibodies. Weinheim: Willey-VCH; 2007.

3. Hust M, Dübel S: Mating antibody phage display to proteomics. Trends Biotechnol 2004, 22:8-14.

4. Taussig MJ, Stoevesandt O, Borrebaeck C, Bradbury A, Dübel S, Frank R, Gibson T, Gold L, Herberg F, Hermjakob H, Hoheisel J, Joos T, Konthur Z, Landegren U, Plückthun A, Ueffing M, Uhlen M: ProteomeBinders: Planning a European Resource of Affinity Reagents for Analysis of the Human Proteome. Nature Methods 2007, 4:13-17.

5. Hoogenboom HR: Selection and screening recombinant antibody libraries. Nat Biotech 2005, 23: I I05-I I I6.

6. Hust M, Dübel S: Phage display vectors for the in vitro generation of human antibody fragments. In Immunochemical Protocols Volume 295. 3rd edition. Edited by: Burns R. Totowa: Humana press; 2005:71-95. [Methods in Molecular Biology]

7. Konthur Z, Hust M, Dübel S: Perspectives for systematic in vitro antibody generation. Gene 2005, 364:19-29.

8. Jostock T, Vanhove M, Brepoels E, Van Gool R, Daukandt M, Wehnert A, Van Hegelsom R, Dransfield D, Sexton D, Devlin M, Ley A, Hoogenboom HR, Mullberg J: Rapid generation of functional human IgG antibodies derived from Fab-on-phage display libraries. J Immunol Meth 2004, 289:65-80.

9. Li H, Sethuraman N, Stadheim TA, Zha D, Prinz B, Ballew N, Bobrowicz P, Choi BK, Cook WJ, Cukan M, Houston-Cummings NR, Davidson R, Gong B, Hamilton SR, Hoopes JP, Jiang Y, Kim N, Mansfield R, Nett JH, Rios S, Strawbridge R, Wildt S, Gerngross TU: Optimization of humanized IgG in glycoengineered Pichia pastoris. Nat Biotech 2006, 24:210-2।5.

10. Twyman RM, Stoger E, Schillberg S, Christou P, Fischer R: Molecular farming in plants: host systems and expression technology. Trends Biotechnol 2003, 2 1:570-578.

II. Skerra A, Plückthun A: Assembly of a functional immunoglobulin Fv fragment in Escherichia coli. Science 1988, 240:1038-104I.

12. Bird RE, Hardman KD, Jacobsen JW, Johnson S, Kaufman BM, Lee SM, Lee T, Pope SH, Riordan GS, Whitlow M: Single-chain antigenbinding proteins. Science 1988, 242:423-426.

13. Huston JS, Levinson D, Mudgett HM, Tai MS, Novotny J, Margolies MN, Ridge RJ, Bruccoloreri RE, Haber E, Crea R, Oppermann H: Protein engineering of antibody binding sites: recovery of specific activity in an anti-digosin single-chain $F v$ analogue produced in Escherichia coli. Proc Natl Acad Sci USA 1988, 85:5879-5883

14. Ward ES: Antibody engineering using Escherichia coli as host. Adv Pharmacol 1993, 24: I-20.

I5. Lauer B, Ottleben I, Jacobsen HJ, Reinard T: Production of singlechain variable fragment antibody against fumonisin B I. J Agricult Food Chem 2005, 53:899-904.

16. Inoue $\mathrm{Y}$, Ohta T, Tada H, Iwasa S, Udaka S, Yamagata H: Efficient production of a functional mouse/human chimeric Fab' against human urokinase-type plasminogen activator by Bacillus brevis. Appl Microbiol Biotechnol 1997, 48:487-492.

17. Shiroza T, Shinozaki-Kuwahara N, Hayakawa M, Shibata Y, Hashizume $T$, Udaka S, Abiko Y: Production of a single-chain variable fraction capable of inhibiting the Streptococcus mutans glucosyltransferase in Bacillus brevis: construction of a chimeric shuttle plasmid secreting its gene product. BBA 2003, 1 626:57-64.

18. Wu SC, Ye R, Wu XC, Ng SC, Wong SL: Enhanced secretory production of a single-chain antibody fragment from Bacillus subtilis by coproduction of molecular chaperons. I Bacteriol 1998, I 80:2830-2835.

19. Wu SC, Yeung JC, Duan Y, Ye R, Szarka SJ, Habibi HR, Wong SL: Functional production and characterization of a fibrin-specific single-chain antibody fragment from Bacillus subtilis: Effects of molecular chaperones and a wall-bound protease on antibody fragment production. Appl Env Microbiol 2002, 68:326I-3269.

20. Vary PS: Prime time for Bacillus megaterium. Microbiology 1994, 140:1001-1013.

21. Malten M, Hollmann R, Deckwer WD, Jahn D: Production and secretion of recombinant Leuconostoc mesenteroides Dextransucrase DsrS in Bacillus megaterium. Biotechnol Bioeng 2005, 89:206-218.

22. Kim JY: Overproduction and secretion of Bacillus circulans endo-beta-I,3-I,4-glucanase gene (bgIBCI) in B. subtilis and B. megaterium. Biotechnol Lett 2003, 25: |445-|449.

23. Burger S, Tatge H, Hoffmann F, Genth H, Just I, Gerhard R: Expression of Clostridium difficile toxin A using the Bacillus megaterium system. Biochem Biophys Res Commun 2003, 307:584-588.

24. Biedendieck R, Beine R, Gamer M, Jordan E, Buchholz K, Seibel J, Dijkhuizen L, Malten M, Jahn D: Export, purification and activities of affinity tagged Lactobacillus reuteri levansucrase produced by Bacillus megaterium. Appl Microbiol Biotechnol in press.

25. Malten M, Biedendieck R, Gamer M, Drews AC, Stammen S, Buchholz $\mathrm{K}$, Dijkhuizen L, Jahn D: A Bacillus megaterium plasmid system for the production, export, and one-step purification of affinity-tagged heterologous levansucrase from growth medium. Appl Environ Microbiol 2006, 72:1677-1679.

26. Yang Y, Biedendieck R, Wang W, Gamer M, Malten M, Jahn D, Deckwer WD: High yield recombinant penicillin $G$ amidase production and export into the growth medium using Bacillus megaterium. Microb Cell Fact 2006, 5:36.

27. Yang Y, Malten M, Grote A, Jahn D, Deckwer WD: Codon optimized Thermobifida fusca hydrolase secreted by Bacillus megaterium. Biotechnol Bioeng in press.

28. Hollmann R, Deckwer WD: Pyruvate formation and suppression in recombinant Bacillus megaterium cultivation. J Biotechnol 2004, I I I:89-96.

29. Wang W, Hollmann R, Deckwer WD: Comparative proteomic analysis of high cell density cultivations with two recombinant Bacillus megaterium strains for the production of a heterologous dextransucrase. Proteome Sci 2006, 4: 19.

30. Ward ES, Güssow D, Griffiths AD, Jones PT, Winter G: Binding activities of a repertoire of single immunoglobulin variable domains secreted from Escherichia coli. Nature 1989, 34I:544-546.

31. Skerra A: A general vector, pASK84, for cloning, bacterial production, and single-step purificaton of antibody Fab fragments. Gene 1994, 141:79-84.

32. Kirsch M, Zaman M, Meier D, Dübel S, Hust M: Parameters affecting the display of antibodies on phage. J Immunol Meth 2005 , 301:173-185

33. Robert R, Clofent-Sanchez G, Hocquellet A, Jacobin-Valat MJ, Daret $D$, Noubhani AM, Santarelli X: Large-scale production, bacterial localization assessment and immobilized metal affinity chromatography purification of a human single-chain Fv antibody against alphallb-beta3 integrin. Int J Biol Macromol 2006, 39:51-59.

34. Rippmann JF, Klein M, Hoischen C, Brocks B, Rettig WJ, Gumpert J, Pfizenmaier K, Mattes R, Moosmayer D: Procaryotic expression of single-chain variable-fragment (scFv) antibodies: secretion in L-form cells of Proteus mirabilis leads to active product and overcomes the limitations of periplasmic expression in Escherichia coli. Appl Environ Microbiol 1998, I 2:4862-9.

35. Kruger C, Hu Y, Pan Q, Marcotte H, Hultberg A, Delwar D, van Dalen PJ, Pouwels PH, Leer RJ, Kelly CG, van Dollenweerd C, Ma JK, Hammarstrom L: In situ delivery of passive immunity by lactobacilli producing single-chain antibodies. Nat Biotechnol 2002, 20:702-6.

36. Pantoliano MW, Bird RE, Johnson S, Asel ED, Dodd SW, Wood JF, Hardman KD: Conformational stability, folding, and ligand- 
binding affinity of single-chain Fv immunoglobulin fragments expressed in Escherichia coli. Biochemistry 1991, 30:10117-10125.

37. Dübel S, Breitling F, Klewinghaus I, Little M: Regulated secretion and purification of recombinant antibodies in E. coli. Cell Biophysics 1992, 21:69-80.

38. Schier R, Bye J, Appel G, McCall A, Adams GP, Malmqvist M, Weiner LM, Marks JD: Isolation of high-affinity monomeric human anti-c-erbB-2 single chain FV using affinity-driven selection. J Mol Biol 1996, 255:28-43.

39. Martineau P, Jones P, Winter G: Expression of an antibody fragment at high levels in the bacterial cytoplasm. J Mol Biol 1998, 280:117-127.

40. Corisdeo S, Wang B: Functional expression and display of an antibody Fab fragment in Escherichia coli: study of vector designs and culture conditions. Protein Expr Purif 2004, 34:270-279.

4l. Dinnis DM, James DC: Engineering mammalian cell factories for improved recombinant monoclonal antibody production: lessons from nature? Biotechnol Bioeng 2005, 91:180-9.

42. Damasceno LM, Anderson KA, Ritter G, Cregg JM, Old LJ, Batt CA: Cooverexpression of chaperones for enhanced secretion of a single-chain antibody fragment in Pichia pastoris. Appl Microbiol Biotechnol in press.

43. Monsellier E, Bedoulle $\mathrm{H}$ : Improving the stability of an antibody variable fragment by a combination of knowledge-based approaches: Validation and mechanisms. I Mol Biol 2006 362:580-593.

44. Carter P, Kelley RF, Rodrigues ML, Snedecor B, Covarrubias M, Velligan MD, Wong WL, Rowland AM, Kotts CE, Carver ME, Yang M, Bourell JH, Shepard HM, Henner D: High level Escherichia coli expression and production of a bivalent humanized antibody fragment. Biotechnology 1992, 10:163-167.

45. Sambrook J, Russell DW, (Eds): Molecular cloning: a laboratory manual. 3rd edition. New York: Cold Spring Harbor Laboratory Press; 2001 .

46. Raux E, Lanois A, Warren MJ, Rambach A, Thermes C: Cobalamin (vitamin BI2) biosynthesis : identification and characterization of a Bacillus megaterium cobl operon. Biochem J 1998, 335:159-166.

47. Wittchen KD, Meinhardt F: Inactivation of the major extracellular protease from Bacillus megaterium DSM319 by gene replacement. Appl Microbiol Biotechnol 1995, 42:87/-877.

48. Barg H, Malten M, Jahn M, Jahn D: Protein and vitamin production in Bacillus megaterium. In Microbial Processes and Products Volume 18. Edited by: Barredo JL. Totowa: Humana press; 2005:205-224. [Methods in Biotechnology]

49. Schmiedl A, Breitling F, Dübel S: Expression of a bispecific dsFvdsFv' antibody fragment in Escherichia coli. Protein Engineering 2000, 13:725-734.

50. Laemmli UK: Cleavage of structural proteins during the assembly of the head of bacteriophage T4. Nature 1970 227:680-685.

\section{Publish with Biomed Central and every} scientist can read your work free of charge

"BioMed Central will be the most significant development for disseminating the results of biomedical research in our lifetime. "

Sir Paul Nurse, Cancer Research UK

Your research papers will be:

- available free of charge to the entire biomedical community

- peer reviewed and published immediately upon acceptance

- cited in PubMed and archived on PubMed Central

- yours - you keep the copyright
BioMedcentral 